Chirurgia (2017) 112: 611-618

No. 5, September - October

Copyright@ Celsius

http://dx.doi.org/10.21614/chirurgia.112.5.611

\title{
Injuries of the Sternoclavicular Joint - An Innovative Approach in the Management of a Rare Injury: Tight Rope Fixation of the Costo-Clavicular Ligament
}

\author{
Jan Unterkofler', David Merschin', Andreas Langenbach ${ }^{2}$, Axel Ekkernkamp", Stefan Schulz-Drost ${ }^{1,2}$ \\ 'Department of Trauma and Orthopedic Surgery, BG Hospital Unfallkrankenhaus Berlin gGmbH, Germany \\ ${ }^{2}$ Department of Trauma Surgery, University Hospital Erlangen, Germany
}

Corresponding author:

Stefan Schulz-Drost, MD, PhD, FEBS

EmSurg.

BG Hospital Unfallkrankenhaus Berlin gGmbH, Warener Straße 7, 12683

Berlin, Germany

E-mail: stefan.schulz-dros@gmx.de

\section{Rezumat}

Leziuni ale articulatiei sternoclaviculare - o abordare inovatoare în tratarea unei leziuni rare: fixarea cu coardă strânsă a ligamentului costoclavicular

Date generale: Ligamentul costoclavicular (CLL) asigură cea mai strânsă stabilitate în cadrul articulației sternoclaviculare (SCJ) urmată de mult citatele ligamentele sternoclaviculare (SCL). Distrugerea lor poate provoca instabilitate severă a SCJ. Opțiunile diferite de tratament, cum ar fi utilizarea plăcilor, a firelor sau a tendoanelor autologe, sunt asociate, în principal, cu rezultate funcționale limitate. Ar putea o stabilizare a CCL asociată cu o fixare anatomică a SCL să asigure o reconstrucție suficientă a SCJ?

Metode: Un bărbat în vârstă de 58 de ani a prezentat o instabilitate anterioară severă şi dureroasă a SCJ după o cădere pe umăr cu 8 săptămâni în urmă. SCJ a fost reconstruit printr-o procedură deschisă, stabilizând CCL folosind 2 coarde strânse şi o sutură anatomică a SCL. Controlul a fost efectuat la 78 de săptămâni după operație.

Rezultate: Reducerea SCJ a avut succes. Investigațile radiologice au demonstrat poziția anatomică a SCJ. Durerea a scăzut în cursul primelor 6 săptămâni. Pacientul a prezentat o evoluție fără complicații şi s-a întors la lucru în calitate de fermier la 6 luni după procedură.

Concluzii: Stabilizarea inovatoare a CCL cu coarde strânse asociată suturii SCL poate permite reconstrucția anatomică a SCJ, ținând cont de rezultatele cosmetice şi funcționale. 
Cuvinte cheie: articulația sternoclaviculară (SCJ), dislocare sternoclaviculară, ligamentul sternoclavicular, ligamentul costoclavicular, coardă strânsă

\begin{abstract}
Background: The costoclavicular ligament (CCL) provides the most tight stability within the sternoclavicular joint (SCJ), followed by the most cited sternoclavicular ligaments (SCL). Their disruption may cause severe instability of the SCJ. Different treatment options, such as the use of plates, wires or autologous tendons are associated with mainly limited functional outcome. Could a stabilization of CCL next to an anatomic fixation of the SCL provide sufficient reconstruction of the SCJ?

Methods: A 58-year-old male showed severe anterior and painful instability of the SCJ following a fall on his shoulder 8 weeks ago. The SCJ had been reconstructed in an open procedure with stabilization of the CCL employing 2 tight ropes and anatomical suture of the SCL. Follow-up was carried out 78 weeks after operation.

Results: The reduction of the SCJ was successful. X-ray proved the anatomic position of the SCJ. Pain was decreased in between the first 6 weeks. The patient showed uneventful follow-up and returned to work 6 months after the procedureas a hard working farmer.

Conclusions: Innovative stabilization of the CCL with tight ropes additional to a suture of the SCL may enable anatomic reconstruction of the SCJ considering cosmetic and functional results.
\end{abstract}

Key words: SCJ joint, sternoclavicular dislocation, sternoclavicular ligament, costoclavicular ligament, tight rope

\section{Introduction}

Injuries of the sternoclavicular joint (SCJ) usually occur due to severe forces against the shoulder girdle during an accident (1). They are known as anisolated entity as well as concomitant to other injuries in relationship to the clavicle or in polytrauma as worst case szenario. The importance of those injuries lies in the specific feature as the SCJ represents the only articulation of the upper limb to the torso (2). Fractures at the medial clavicle with involvement of the SCJ are a common injury as well as a distorsion of the SCJ with complete or partial disrupture of its strong ligaments.

The costoclavicular ligament (CCL) provides the most tight stability followed by the most cited sternoclavicular ligaments (SCL) which connect the joint in a posterior and in an anterior part $(3,4)$.

Severe instability is mainly caused by the disruption of the SCL and the CCL in combination (5). The medial clavicle can either dislodge into a frequently observed anterior dislocation or, more rarely, posteriorly. This, in turn, is more frequently associated with complications from the mediastinal lesions, for example, a vascular lesion of the anonymous vein or compression of the trachea $(6,7,8)$. Both dislocation forms have a painful limitation of the movement of the arm and a possibly severe instability of the medial clavicle. This was described by Allmann as a function of the extent of the ligament injury [Table 1, (9)].

Possible treatment options are described in a large variety employing the fixation of the clavicle against the manubrium through a sternoclavicular plate at the anterior surface thus archieving a functional arthrodesis or a hook plate $(10,11)$. With the aim to provide a more functional result, the stabilization of the SCJ had been widely described by sternoclavicular sutures, wires or autologous tendons 
Table 1. The Allmann Classification of sternoclavicular dislocations

\begin{tabular}{|c|c|c|}
\hline \multicolumn{3}{|c|}{ Dislocations of the Sternoclavicular joint (Allmann 1967) } \\
\hline I & mild distorsion & $\begin{array}{l}\text { minor pain } \\
\text { no instability }\end{array}$ \\
\hline$\|$ & incomplete dissociation & $\begin{array}{l}\text { possible pain, swelling and } \\
\text { local instability/subluxation } \\
\text { disruption of the SCL } \\
\text { (anterior, posterior or both) } \\
\text { intact CCL (or minor distorsion) }\end{array}$ \\
\hline |l| & complete dissociation & $\begin{array}{l}\text { pain, swelling, instability } \\
\text { possible dislocation/complete } \\
\text { luxation (anterior or posterior) } \\
\text { disruption of the SCL and the } \\
\text { CCL }\end{array}$ \\
\hline
\end{tabular}

in order to stabilize the destroyed parts of the SCL $(12,13,14)$.

Since those techniques had been often associated with limited functional outcome and a high rate of a recurrent instability, some techniques already focus on the need of a stabilization of the strong CCL as an important stabilizer of the SCJ. Mainly complex procedures had been described in this matter, such as wrapping with a non resorbable mesh, a tendon transfer of the sternocleidomastoideus muscle after its split or again a plasty with the use of autologous tendons such as the one from the gracilis muscle $(15,16)$.

Common to all techniques is, besides a high invasiveness of the method, moderately good functional results and recurring pain. The frequently described resection of the SCJ can also be associated with similar complaints (17).

The purpose of this report is to answer the question whether a reconstruction of CCL next to an anatomic fixation of the SCL can provide sufficient stability and functionality of the SCJ through a TightRope ${ }^{\circledR}$ (Arthrex, Munich, Germany) augmentation.

This innovative operative technique will be described in detail.

\section{Material and Method}

A case report of a SCJ dislocation with anterior displacement and a high degree of instability had been followed up continuously for 18 months after the operative treatment.

\section{The Accident}

A 58-year-old farmer slipped off the steps of his tractor while climbing on it and fell to the ground about 1.5 meters. He sustained considerable injuries to the right hemithorax at the impact on the ground with his right shoulder. The injury pattern consisted of a rib series fracture, accompanying pneumothorax, an Acromioclavicular joint (ACJ) dislocation, type Tossy II and an anterior dislocation of the right SCJ, type Allmann III.

As a pre-existing disease there were a moderate omarthrosis on the right side and arterial hypertension.

\section{The Healing Process}

The patient was initially admitted at a local hospital for 10 days, where he received a chest tube as well as conservative therapy of the rib fracture series with analgesia, physiotherapy and respiratory therapy. In this regard the injuries healed without complication.

The right arm was immobilized for a few days in a bandage before carefully physiotherapeutic exercises were done. After a couple of days the acute pain and local swelling decreased, however, there was still a visible malposition of the SCJ as well as movement restriction, instability and pain during movement.

After assignment to our Trauma Center, there was an ongoing, anterior dislocation position of the SCJ with rupture of the SCL and CCL which could be proven in the MRI.

The indication for operative revision was made. The patient agreed with the treatment proposal and agreed to the procedure.

\section{The Operative Treatment}

The SCJ had been reconstructed in an open procedure with stabilization of the CCL employing 2 tight ropes and anatomical suture of the SCL. Tight ropes had been placed through the medial clavicle and the $1^{\text {st }}$ rib anatomically. The operation had been done in a supine position under general anaesthesia.

After disinfection of the skin, the land- 
marks of the manubrium, the clavicle, and the sternocleidomastoid muscle are indicated and an arch-shaped incision is applied, followed by the subcutaneous dissection up to the joint capsule of the SCJ.

The pectoralis major muscle is carefully detached from the medial clavicle and the manubrium edge to gain insight into the entire anterior SCL and the subclavicular CCL. If the joint capsule is closed, it is sharply split in the axis direction of the clavicle and the joint is inspected. In the case of injury, the articular discus is either smoothed, sewn, or resected when dislocation occurs.

Now the foodprint of the CCL is inspected and, if necessary, refreshed with a sharp instrument, both rib sided and clavicular. On the underside of the first rib, the perichondrium is carefully incised and lifted from the posterior wall. The elongated foodprint of the CCL is used to create two drill channels with a target device: from the upper edge of the clavicle to the lower edge of the first rib.

Flexible Nitinol guide wires are inserted through these holes and carefully gripped at the lower edge of the first rib and pulled into the operating field. These cables are used to connect the TightRope ${ }^{\circledR}$ loop and pull the flipdisc through the drill channel. As soon as the flipdisc has securely anchored itself at the lower edge of the first rib, the clavicle is repositioned into the anatomical position and the TightRopes ${ }^{\circledR}$ is tensioned, followed by securing nodes. The stability is checked by careful movement of the arm.

In the next step, the SCL is reconstructed by a figure of eight suture over the manubrioclavicular transition, followed by a reconstruction of the ligament and capsular facets with strong, slowly resorbable sutures (e.g., PDS). A capsule doubling provides additional stability and tightening of the often elongated anterior capsule.

Finally, a pleural drainage and a subcutaneous one are inserted and then the wound is closed layer by layer, including the refixing of the pectoralis major on the clavicle and sternum.

6 weeks postoperatively, the patient is advised to restrict the movement of his arm below the $90^{\circ}$ plane as well as to avoid jerky forward or backward movements.

\section{Radiographs}

For the follow-up examinations, both SCJs were $\mathrm{x}$-rayed in 3 projections on the sides: anterior-posterior, $40^{\circ}$ obliquely from the head upwards to the assessment of the translational dislocation and $40^{\circ}$ obliquely from the foot to the assessment of the vertical dislocation of the medial clavicle [Serendipity view $(18,19)$; Fig. 1].

\section{Follow up}

Follow up had been carried out after 2, 6, 12, 26, 52 and 78 weeks at which a clinical examination and an X-ray follow up had been done.

\section{Results}

The reduction of the SCJ was successful. X-ray proved the anatomic position of the SCJ. Pain was decreased in between the first 6 weeks. The patient showed uneventful follow up and returned to work as a hard working farmer 6 months after the procedure.

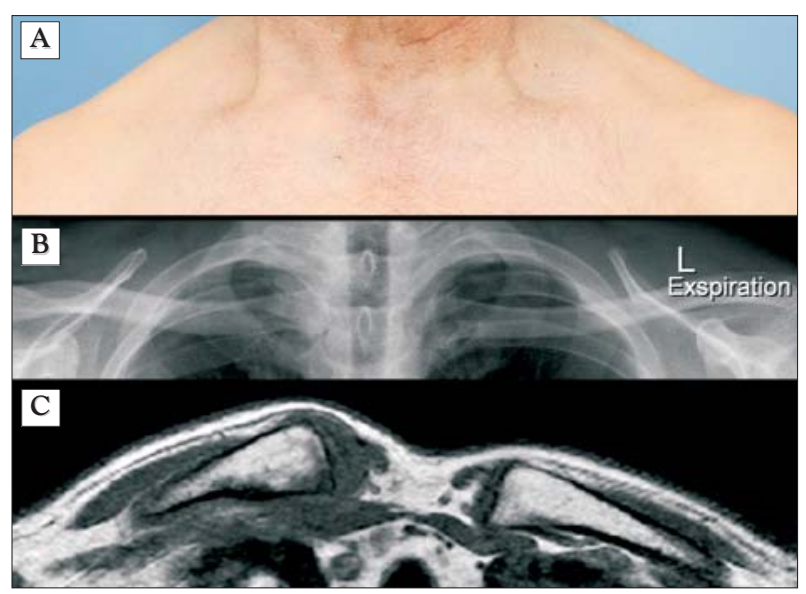

Figure 1. Initial situation - anterior dislocation of the right SCJ, Type Allmann III. (A) The clinical view shows the protrusion of the medial clavicle on the right side. (B) The dislocation of the right SCJ is clearly visible in the anterior-posterior X-ray. (C) MRI confirmes the dislocation of the right SCJ and proofs the disruption of the CCL in addition. 


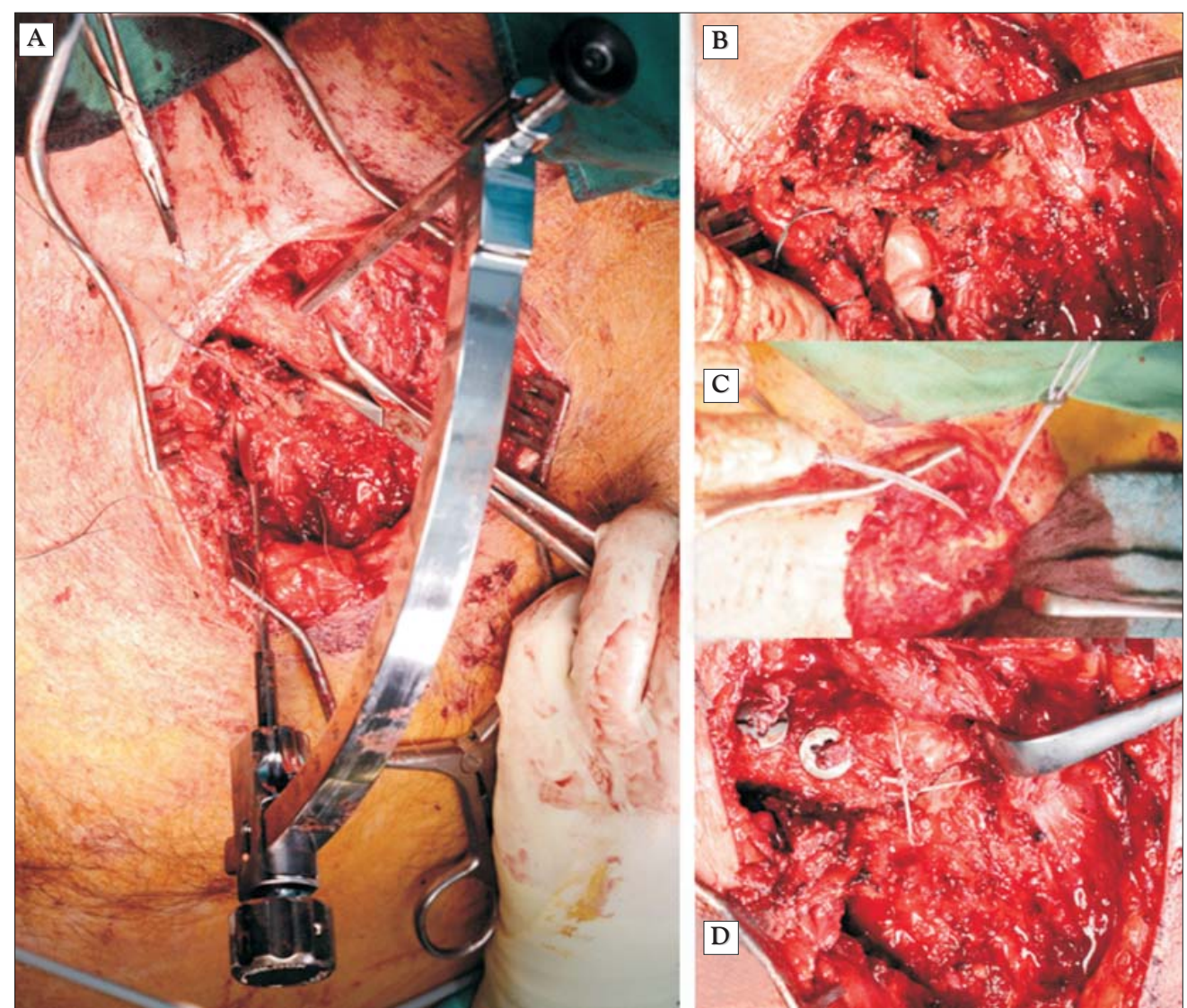

Figure 2. The operative procedure. (A) Performing the drill holes from the superior aspect of the medial clavicle surpassing the anatomic foodprint of the SCL and the first rib to its inferior aspect. A drill guide assists and secures the correct direction of the drilling. (B) A nitinol wire is passed through the hole which allows to shuttle the flip disc of the tight rope and its filaments. The edges of the articular capsule of the SCJ had been armed with temporary sutures (green filaments on the left bottom) as well as the edges of the anterior SCL. (C) A second TightRope ${ }^{\circledR}$ is placed following the same steps. The upper suture discs as well as their strong quadrupel filamentsare clearly visible. (D) Two tight ropes secure the correct position of the medial clavicle with their knots. An additional sternoclavicular cerclage is performed by a strong non resorbable filament (TigerWire $\circledast$, Arthrex, Munich, Germany) which is placed with a figure of eight stitch at the anterior aspect of the SCJ. Following this step the soft tissue is closed with strong PDS (USP 0, Ethicon, Summerville, NewJersey, USA) stitches layer by layer starting with the articular capsule of the SCJ and the anterior part of the SCL.

\section{Soft Tissue Healing}

After surgery, the patient was hospitalized for 10 days. The wound healed by primam without complication. Both drainages could be removed after two days. A moderate swelling of the soft tissue almost completely subsided until the second week, until the $6^{\text {th }}$ week without any residuals.

Up to 12 weeks of follow up, the peri-articular wefts of the right SCJ were clearly visible and palpable in side comparison. The further investigations showed a slow adjustment of the protrusion up to the $52^{\text {nd }}$ week with stable scarring.

\section{Agility}

By the end of the 6 week, we only released pendulum exercises of the shoulder in the lower range of motion, then the mobility was slowly increased. After the $12^{\text {th }}$ week a 6 -week intensive treatment at a health resort with 
multimodal physical therapy and physiotherapy was carried out. The mobility could be increased to $140^{\circ}$ anteversion and abduction of the shoulder, while the shoulder was free to move. Residual complaints were more interesting, especially by the conservative ACJ injury, for a few weeks, while the region around the SCJ was almost free of complaints.

On the $26^{\text {th }}$ week, the patient showed a mobility of $150^{\circ}$, and, after 52 weeks, $170^{\circ}$, equal and free mobility of the shoulder.

\section{End Result}

The patient returned to work as a farmer after 6 months. The mobility of the shoulder was completely restored, as was the stability of the SCJ. The patient experienced moderate discomfort up to the $52^{\text {nd }}$ week. These have been reduced to a minimum until recently.

\section{Discussions}

The SCJ is a special joint. On the one hand, it is the only bony connection that makes contact between the arm and the trunk. An interaction of intricately arranged ligaments, a very elastic joint capsule and an intraarticular discus mediate the enormous degrees of freedom of movement of this joint. On the other hand, the most powerful of the ligaments, the CCL counteracts an overstraining of the SCL by keeping the medial clavicle firmly in spatial relation to the first rib $(20,21,22)$.

Thus, the joint pit of the manubrium sterni, together with the medial head of the clavicle and the first rib, form a joint complex held by a complex ligament system and guided in motion.

Severe force must be applied to tear these ligaments and dislodge the medial clavicle from the anatomical position.

It is quickly understood that reconstructions of such ligament injuries require just as complex considerations as their anatomical structure per se.

For this reason, injuries of the medial clavicle in the system of the German statutory accident insurance are treated by specially

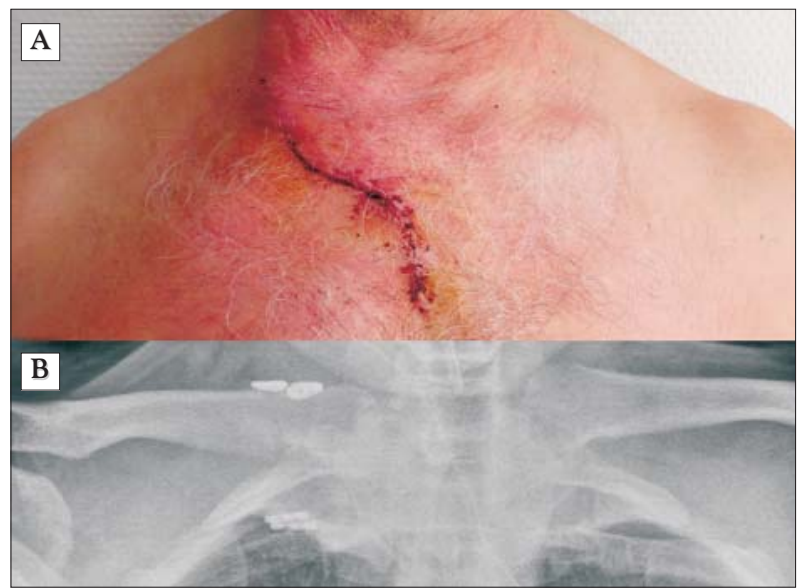

Figure 3. Postoperative result. (A) Theoperative approach with remaining swelling of the soft tissue 7 days postoperatively. Both medial clavicle show a symmetric position. (B) Postoperative X-ray (Serendipity-view). The medial clavicle hasbeen fixed to the first rib with two TightRopes $®$ in the position of the CCL. There is no dislocation remaining.

qualified traumatologists within certified hospitals for the very severe injury procedure [SAV (23)].

Unfortunately, only a few surgeons have experience in larger case series and their longterm follow-up.

The literature is also mostly based on case reports and describes a variety of different treatment methods.

Two important points, as mentioned at the outset, should be included in the considerations of an SCJ reconstruction:

On the one hand, the extent of the ligament destruction should be clearly defined and should be taken into consideration during the reconstruction procedure. The strong CCL seems to play a special role, wherefore its reconstruction is recommended.

On the other hand, the question of the type of reconstruction arises, which can in principle be achieved by means of a filament-augmentation of the ligament residues by seams or by replacing them with autologous tendon transplantation (24). The latter always entail a risk of complications at the donorsite of the tendons, which are widely known in the context of other ligament reconstructions such as at the knee or the ankle (25). 
However, very potent augmentation methods with non-resorbing filament bundles and bony anchoring by titanium platelets have recently been described. This technique for the anatomical augmentation of the coracoclavicular ligaments is also applied with great success for ACJ as wells as in the repair of the crucial ligaments at the knee and the syndesmosis at the ankle $(26,27)$.

Therefore, the question came up if a successful application for the reconstruction of the CCL was possible, avoiding local musclesplicing or tendon-grafting procedures.

In the case shown here, two TightRope ${ }^{\circledR}$ bundles were inserted along the lateral and the medial course of the CCL. The anatomical, slightly converging direction of the CCL bundles was thus reconstructed, which prevents a relative movement of the clavicle to the first rib.

The long-term follow-up showed an excellent functional result of the method.

In addition to biomechanical investigations, further systematic case observations should be the focus of future efforts to scientifically evaluate this promising method.

\section{Conclusions}

Innovative stabilization of the CCL with TightRopes $^{\circledR}$ additional to a suture of the SCL may enable anatomic reconstruction of the SCJ considering cosmetic and functional results.

\section{Acknowledgements}

We thank Mrs. Becht and Professor Mutze and the team from the institute of radiology for the friendly support in providing the X-Rays as well as the establishment of an in housestandard for the imaging in injuries of the medial clavicle. Furthermore we thank Mrs.Scheurlen from the photographic department for her kindly support in providing the clinical figures.

\section{Concflicts of Interest}

The senior author has a consultant agreement with DePuySynthes and he is an advisory member of the AO TK Thoracic Surgery Expert Group (THEG).

\section{Ethical Policies}

This is a retrospective study. No experiments on humans or animals had been done.

\section{Financial Support}

No funds had been received in connection to this study.

\section{References}

1. Sewell MD, Al-Hadithy N, Le Leu A, Lambert SM. Instability of the sternoclavicular joint: current concepts in classification, treatment and outcomes. Bone Joint J. 2013;95-B(6):721-31. doi: 10.1302/ 0301-620X.95B6.31064.

2. Spencer EE, Kuhn JE, Huston LJ, Carpenter JE, Hughes RE. Ligamentous restraints to anterior and posterior translation of the sternoclavicular joint. J Shoulder Elbow Surg. 2002;11(1):43-7.

3. Lee JT, Campbell KJ, Michalski MP, Wilson KJ, Spiegl UJ, Wijdicks $\mathrm{CA}$, et al. Surgical anatomy of the sternoclavicular joint: a qualitative and quantitative anatomical study. J Bone Joint Surg Am. 2014;96(19):e166. doi: 10.2106/JBJS.M.01451.

4. CAVE AJ. The nature and morphology of the costoclavicular ligament. J Anat. 1961;95:170-9.

5. Thomas DP, Williams PR, Hoddinott HC. A 'safe' surgical technique for stabilisation of the sternoclavicular joint: a cadaveric and clinical study. Ann R CollSurg Engl. 2000;82(6):432-5.

6. di Mento L, Staletti L, Cavanna M, Mocchi M, Berlusconi M. Posterior sternoclavicular joint dislocation with brachiocephalic vein injury: a case report. Injury. 2015;46 Suppl 7:S8-10. doi: 10.1016/S0020-1383(15)30036-X.

7. Jaggard MK, Gupte CM, Gulati V, Reilly P. A comprehensive review of trauma and disruption to the sternoclavicular joint with the proposal of a new classification system. J Trauma. 2009;66(2): 576-84. doi: 10.1097/TA.0b013e31817fd96b.

8. Fenig M, Lowman R, Thompson BP, Shayne PH. Fatal posterior sternoclavicular joint dislocation due to occult trauma. Am J Emerg Med. 2010;28(3):385.e5-8. doi: 10.1016/j.ajem.2009.05.011.

9. Allman FL Jr. Fractures and ligamentous injuries of the clavicle and its articulation. J Bone Joint Surg Am. 1967;49(4):774-84.

10. Quispe JC, Herbert B, Chadayammuri VP, Kim JW, Hao J, Hake M, et al. Transarticular plating for acute posterior sternoclavicular joint dislocations: a valid treatment option? Int0rthop. 2016;40(7): 1503-8. doi: 10.1007/s00264-015-2952-y. Epub 2015 Aug 11.

11. Franck WM, Jannasch O, Siassi M, Hennig FF. Balser plate stabilization: an alternate therapy for traumatic sternoclavicular instability. J Shoulder Elbow Surg. 2003;12(3):276-81.

12. Adamcik S, Ahler M, Gioutsos K, Schmid RA, Kocher GJ. Repair of sternoclavicular joint dislocations with FiberWire ${ }^{\circledast}$ Arch Orthop Trauma Surg. 2017;137(3):341-345. doi: 10.1007/s00402-017-2632-z.

13. Martínez A, Rodríguez A, González G, Herrera A, Domingo J. Atraumatic spontaneous posterior subluxation of the sternoclavicular joint. Arch Orthop Trauma Surg. 1999;119(5-6):344-6.

14. Lehmann W, Laskowski J, Grossterlinden L, Rueger JM. Refixation of sternoclavicular luxation with a suture anchor system. Unfallchirurg. 2010;113(5):418-21. 
15. Thyagarajan $\mathrm{D}$, Webb $\mathrm{M}$, Wallace $\mathrm{A}$. A rare case of floating clavicle and a novel technique for stabilizing the sternoclavicular joint. 2015; 7(1):44-8. doi: 10.1177/1758573214536534.

16. Booth CM, Roper BA. Chronic dislocation of the sternoclavicular joint: an operative repair. Clin Orthop Relat Res. 1979;(140):17-20.

17. Morell DJ, Thyagarajan DS. Sternoclavicular joint dislocation and its management: A review of the literature. World J Orthop. 2016; 7(4):244-50. doi: 10.5312/wjo.v7.i4.244

18. Rockwood CA, Green DP, Bucholz RW, Fractures in Adults. Philadelphia: Lippincot; 1991. p. 1253-1307.

19. Garretson RB 3rd, Williams GR Jr. Clinical evaluation of injuries to the acromioclavicular and sternoclavicular joints. Clin Sports Med. 2003;22(2):239-54.

20. Tubbs RS, Shah NA, Sullivan BP, Marchase ND, Cömert A, Acar HI, et al. The costoclavicular ligament revisited: a functional and anatomical study. Rom J Morphol Embryol. 2009;50(3):475-9.

21. Negri JH, Malavolta EA, Assunçăo JH, Gracitelli ME, Pereira CA, Bolliger Neto $R$, et al. Assessment of the function and resistance of sternoclavicular ligaments: A biomechanical study in cadavers. Orthop Traumatol Surg Res. 2014;100(7): 727-31. doi: 10.1016/ j.otsr.2014.07.011.

22. Seyhan M, Donmez F, Mahirogullari M, Cakmak S, Mutlu S, Guler 0 . Comparison of screw fixation with elastic fixation methods in the treatment of syndesmosis injuries in ankle fractures.Injury. 2015; 46 Suppl 2:S19-23. doi: 10.1016/j.injury.2015.05.027. Epub 2015 Jun 24.

23. Verletzungsartenverzeichnis mit Erläuterungen unter Einschluss des Schwerstverletzungsartenverfahrens. DGUV, SVLFG 1. Juli 2014. http://www.dguv.de/medien/landesverbaende/de/med_reha /documents/verletz3.pdf

24. Martetschläger F, Warth RJ, Millett PJ. Instability and degenerative arthritis of the sternoclavicular joint: a current concepts review. Am J Sports Med. 2014;42(4):999-1007. doi: 10.1177/ 0363546513498990.

25. Inderhaug E, Strand T, Solheim E. The impact of sensory deficits after harvesting hamstrings autograft for $A C L$ reconstruction. Knee Surg Sports Traumatol Arthrosc. 2015;23(4):1060-4. doi: 10.1007/ s00167-014-2871-2.

26. Motta P, Bruno L, Maderni A, Tosco P, Mariotti U. Acute lateral dislocated clavicular fractures: arthroscopic stabilization with TightRope.J Shoulder Elbow Surg. 2014;23(3):e47-52. doi: 10.1016/ j.jse.2013.05.016.

27. Robert H, Bowen M, Odry G, Collette M, Cassard X, Lanternier H, et al. A comparison of four tibial-fixation systems in hamstring-graft anteriorligament reconstruction.Eur J Orthop Surg Traumatol. 2015;25(2):339-47. doi: 10.1007/s00590-014-1473-5. 